\title{
Edukacja dla zrównoważonego rozwoju w szkołach ponadgimnazjalnych.
}

\author{
Niszczenie środowiska przy braku odpowiedniej wiedzy \\ przypomina podcinanie gatęzi, na której sami siedzimy... \\ Jan Paweł II
}

\section{Wstęp}

Większość z nas żyje na co dzień w przeludnionym i zabudowanym „betonem świecie”. Jeśli zapragniemy kontaktu z przyrodą wyruszamy w odległe zakątki, szukając niezdewastowanego jej fragmentu. Coraz częściej okazuje się, że poszukiwaniom tym towarzyszą ogromne trudności. Niewiele osób zdaje sobie sprawę z nadmiernej eksploatacji środowiska przyrodniczego i konsekwencji, jakie to za sobą niesie. Przyczyna obecnej kondycji środowiska tkwi w nas samych, czyli w braku świadomości na temat naszych negatywnych działań związanych z wieloma prozaicznymi czynnościami życia codziennego. Oddziaływania człowieka na środowisko noszą nazwę wpływów antropogenicznych. Jeżeli wpływy te są wyjątkowo silne lub rozciągnięte w czasie i powodują duże obciążenia, mówimy wtedy o antropopresji. Wpływy te nie zamykają się jedynie w obrębie lokalnym, czy regionalnym, ale mają zasięg globalny.

\section{Przestrzeganie zasad zrównoważonego rozwoju}

Do konieczności przestrzegania zasad ochrony przyrody odnosił się w swoich wystąpieniach wielokrotnie Jan Paweł II, m.in. w Encyklice Centessimus Annus, z 1991 r., czytamy „Człowiek, opanowany pragnieniem posiadania i użycia bardziej aniżeli bycia i wzrastania, zużywa w nadmiarze i w sposób nieuporządkowany zasoby ziemi, narażając przez to także własne życie. U korzeni bezmyślnego niszczenia środowiska naturalnego tkwi błąd antropologiczny, niestety rozpowszechniony w naszych czasach. Człowiek, który odkrywa swą zdolność przekształcania i w pewnym sensie stwarzania świata własną pracą, zapomina, 
że zawsze dzieje to przez pierwszy dar otrzymany od Boga na początku w postaci rzeczy przezeń stworzonych.” I dalej: „Współczesna ludzkość winna być świadoma swych obowiązków i zadań, jakie w tej dziedzinie spoczywają na niej wobec przyszłych pokoleń" (Jan Paweł II, 1998).

Celem opracowanego materiału jest prezentacja uzyskanych wyników z przeprowadzonych badań dotyczących ustalenia, w jakim stopniu wprowadzane są zagadnienia zrównoważonego rozwoju na zajęciach edukacyjnych, jak również poznanie jaki wpływ ma realizacja tej tematyki na kształtowanie świadomości prośrodowiskowej młodego człowieka.

Koncepcja trwałego i zrównoważonego rozwoju została przyjęta jako wiodąca zasada rozwoju społeczno-gospodarczego i wytyczna gospodarowania środowiskiem przyrodniczym w Unii Europejskiej. W Polsce koncepcji tej nadano rangę zasady konstytucyjnej, której cechą charakterystyczną jest otwartość w sensie teoretyczno - koncepcyjnym i aplikacyjnym. Dlatego powinna ona być stale doskonalona stosownie do rozwoju teorii naukowych, specyfiki kraju i doświadczeń we wdrażaniu.

Już wiele osób uświadomiło sobie fakt, że zrównoważony rozwój jest aktualnie istotnym wyzwaniem dla kształtowania świadomości nie tylko danych grup społecznych, lecz również w szerszym rozumieniu, ogółu obywateli. Podejmując tę problematykę należy zwrócić szczególną uwagę na rolę edukacji w propagowaniu idei odpowiedzialności za środowisko naturalne. Szczególnie ważnym elementem kształcenia w myśl zasad edukacji prośrodowiskowej jest podjęcie wszelkich działań w placówkach szkolnych, których celem jest stymulowanie świadomości środowiskowej młodzieży, a także przygotowanie kadry pedagogicznej do wdrażania szeregu metod i strategii pozwalających na uzyskanie jak najlepszych wyników podczas edukowania młodego pokolenia.

\section{Edukacja na rzecz zrównoważonego rozwoju}

Dlatego należy niezwłocznie podjąć odpowiednie przedsięwzięcia w celu wspomagania edukacji w kształtowaniu wartości i pozytywnych postaw dotyczących realizacji VI Programu Środowiskowej Polityki Unijnej, a także wyeksponować nośną idę̨ tego programu: „Nasza przyszłość zależy od naszego wyboru”.

Kształtowanie tych wartości powinno odbywać się przez odpowiednie ksztalcenie, które jest złożonym procesem łączącym w sobie nauczanie i uczenie się, prowadzące do zdobywania wiadomości i umiejętności, a także nabywanie odpowiednich, prawidłowych postaw i nawyków pozwalających na funkcjonowa-

Cichy D. 2005: Edukacja środowiskowa wzmocnieniem zrównoważonego rozwoju. Instytut Badań Edukacyjnych. Wyższa Szkoła Pedagogiczna ZNP, Warszawa s. 5. 
nie w społeczeństwie. Szereg tych procesów ma także za zadanie wpajać nawyki systematycznego i samodzielnego wdrażania wiedzy w życie codzienne, chęci do indywidualnej oraz zespołowej działalności. Rozważając założenia edukacji w myśl zrównoważonego rozwoju, należy zdefiniować samo jej pojęcie, które obok kształcenia, jest kluczowym w kształtowaniu świadomości prośrodowiskowej i wychowaniu.

Edukacja - to proces zdobywania wiedzy, umiejętności, najczęściej przewidzianych programem. ${ }^{2}$

Edukacja pozwala poznać i zrozumieć relacje z otaczającym nas światem, wyjaśnić procesy w nim zachodzące, a także nauczyć prawidłowego funkcjonowania. Ideą edukacji na rzecz zrównoważonego rozwoju jest dążenie do osiągnięcia równowagi pomiędzy społecznym i ekonomicznym dobrem oraz kulturą, tradycją i ochroną zasobów naturalnych. Edukacja na rzecz zrównoważonego rozwoju podkreśla potrzebę respektowania godności ludzkiej, poszanowania różnorodności, ochrony środowiska naturalnego i zasobów naszej planety. Ideałem, do którego należy dążyć, jest zapewnienie każdej jednostce możliwości kształcenia zgodnego z jej zdolnościami oraz wpajanie w procesie kształcenia wartości, bez których niemożliwy byłby zrównoważony rozwój społeczny. Warunkiem koniecznym do spełnienia jest nieustanny monitoring jakości procesu kształcenia. ${ }^{3}$

Ogół procesu kształcenia dotyczący wiadomości zawierających idee prośrodowiskowe i ekorozwoju nazywamy edukacją środowiskową, która nie bez powodu odnosi się do założeń zrównoważonego rozwoju. Jest ona ważnym ogniwem w procesie kształcenia i odgrywa kluczową rolę w kształtowaniu postaw i świadomości nie tylko młodzieży szkolnej lecz również całego społeczeństwa.

Edukacja w tym zakresie kształtuje świadomość i budzi zainteresowanie całego społeczeństwa wzajemnie powiązanymi kwestiami ekologicznymi, ekonomicznymi, społecznymi i politycznymi. Umożliwia zdobywanie wiedzy i umiejętności niezbędnych do poprawy stanu środowiska, tworzy nowe wzorce zachowań, kształtuje postawy i przekonanie jednostek, grup społecznych, uwzględniając troskę o jakość środowiska. Powinna ona obejmować całe społeczeństwo, wszystkie grupy wiekowe, zawodowe, a także elity władzy na szczeblu centralnym i lokalnym. ${ }^{4}$

Aby realizacja wyżej wymienionych celów była możliwa, niezbędne jest:

- Uznanie, iż edukacja ekologiczna jest jednym z podstawowych warunków Polityki Ekologicznej Państwa.

Słownik Współczesnego Języka Polskiego tom l. WILGA, Warszawa. 1998 s. 226.

3 Bielska A. 2006: Rola Ministerstwa Srodowiska w Kształtowaniu świadomości Ekologicznej Społeczeństwa. Edukacja Biologiczna i Srodowiskowa. nr 3 s. 25.

4 Bielska A. 2006: Rola Ministerstwa Środowiska w Kształtowaniu Świadomości Ekologicznej Społeczeństwa. Edukacja Biologiczna i Srodowiskowa. Kwartalnik dla Nauczycieli nr 3(19) s. 24. 
- Wprowadzenie elementów edukacji ekologicznej do wszystkich sfer życia społecznego z uwzględnieniem i wykorzystaniem wartości kulturalnych, etycznych i religijnych.

- Zapewnienie dostępu społeczeństwa do informacji o stanie środowiska naturalnego i edukacji ekologicznej.

- Uznanie, że edukacja ekologiczna jest podstawowym warunkiem zmiany konsumpcyjnego modelu życia społeczeństwa. ${ }^{5}$

Edukacja środowiskowa powinna zmierzać do ściślejszego powiązania procesów nauczania i rzeczywistości, skupiając swe czynności wokół problemów środowiska, które wyłaniają się z określonych skupisk ludzi, analizować te problemy, zajmować pozycje międzydyscyplinarne i globalne, które pozwalają na ich zrozumienie. ${ }^{6}$

Na podstawie analizy podstawy programowej obowiązującej w szkołach można twierdzić, że edukacja środowiskowa w nowym systemie kształcenia została potraktowana marginalnie. Szczególną uwagę należy zwrócić na mały wymiar propozycji tematycznych związanych z wprowadzeniem „idei zrównoważonego rozwoju”. A przecież Podstawa programowa przedmiotów ogólnokształcących nakłada na nauczycieli wszystkich typów szkół obowiązek przygotowania uczniów do podejmowania działań na rzecz wyposażenia ich w niezbędny zasób wiedzy z zakresu ekologii i ochrony środowiska oraz wykształcenia wrażliwości na globalne problemy.

\section{Analiza uzyskanych danych z przeprowadzonych badań}

W celu poznania opinii uczniów kieleckich szkół ponadginazjalnych na temat wprowadzania i realizacji treści dotyczących zrównoważonego rozwoju przeprowadzono badania sondażowe.

Badaniami objęto 150 uczniów na czwartym etapie edukacyjnym w klasie trzeciej szkoły ponadgimnazjalnej, wśród ankietowanych 39\% to chłopcy, zaś dziewczęta stanowiły $61 \%$ populacji. Właściwą interpretację określenia ekorozwój podało tylko 54 osoby, natomiast 84 błędną, a 12 nie udzieliło żadnej odpowiedzi. Najwięcej prawidłowych wyjaśnień udzielili uczniowie z klas, gdzie biologia realizowana jest $w$ kanonie rozszerzonym. Zdaniem respondentów nauczyciele najczęściej omawiają zagadnienia ekorozwoju na następujących przedmiotach nauczania:

5 Bielska A. 2006: Rola Ministerstwa Srodowiska w Kształtowaniu Ŝwiadomości Ekologicznej Społeczeństwa. Edukacja Biologiczna i Środowiskowa. Kwartalnik dla Nauczycieli nr 3 (19) s. 24.

6 Cichy D. 2005: Uwarunkowania edukacji dla zrównoważonego rozwoju. [w:] Edukacja środowiskowa wzmocnieniem zrównoważonego rozwoju. Red. D. Cichy IBE, WSP ZNP, Warszawa s. 26. 
- biologia $-53 \%$

- geografia - $21 \%$

- chemia $-14 \%$

- lekcja do dyspozycji wychowawcy - $6 \%$

- fizyka-2\% (według kolejności wskazań uczniów).

Natomiast 4\% uczniów uważa, że na zajęciach edukacyjnych te zagadnienia nie pojawiły się.

Zdaniem respondentów tematyka $\mathrm{z}$ zakresu ekologii i ochrony środowiska jest wdrażana przede wszystkim na lekcjach prowadzonych w klasie metodą badawczą (doświadczenia) oraz na często odbywających się zajęciach terenowych, ale tylko w klasach $\mathrm{z}$ rozszerzoną biologią - 25,8\% takich odpowiedzi. $14,9 \%$ uczniów wskazało, że zajęcia w sali lekcyjnej mogą być również prowadzone metodą obserwacyjną. Według $13,7 \%$ zajęcia terenowe, na których mogłaby być wdrażana taka problematyka, nie odbywają się w klasach o profilu podstawowym. Zielone szkoły są również miejscem zdobywania wiedzy środowiskowej według $18,2 \%$, natomiast $10,1 \%$ wskazało, że nie odbywają się one wcale.

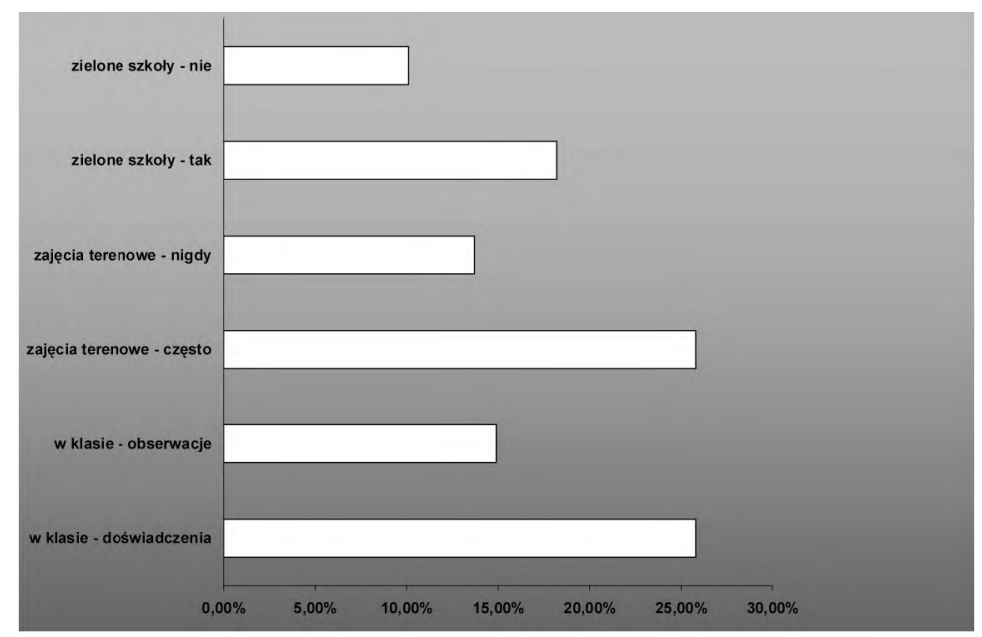

Ryc. 1. Miejsce zajęć z ekologii i ochrony środowiska.

Najwięcej ankietowanych, bo aż 48\%, oceniło te zajęcia na 8 punktów. Najwyższą notę, 10 przyznało tylko $5 \%$ respondentów, a 33\% oceniło stosunkowo nisko przyznając im tylko 4 punkty w dziesięciopunktowej skali ocen. Zagadnieniami związanymi z ekorozwojem interesuje się 39.3\% uczniów. Zainteresowań takich nie przejawia $47 \%$, a $13.7 \%$ nie zadeklarowało żadnej odpowiedzi. Dziewczęta wykazują mniejsze zainteresowanie tymi zagadnieniami niż chłopcy. W przeprowadzonych badaniach próbowano również ustalić wpływ 
przekazywanych informacji podczas różnorodnych zajęć edukacyjnych na rozwój zainteresowań uczniów zagadnieniami z zakresu ekologii i ochrony środowiska.

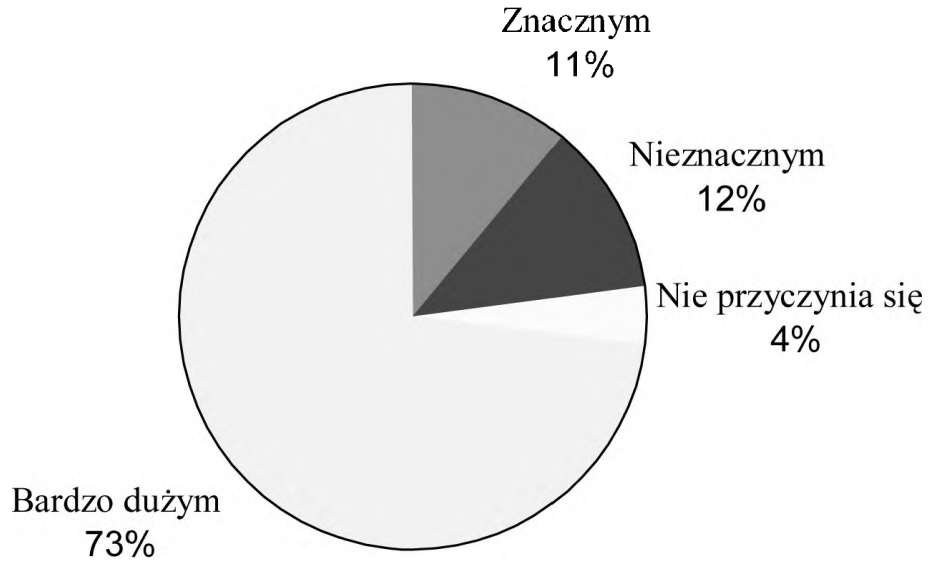

Z uzyskanych danych można wnioskować, że zajęcia edukacyjne prowadzone w szkole wpływają pozytywnie na rozwijanie zainteresowań tą problematyką (84\% - skumulowane odpowiedzi: bardzo dużym i znacznym zakresie). W kwestionariuszu ankiety zamieszczono także pytanie dotyczące przedsięwzięć proekologicznych, w których młodzież aktywnie brała udział.

Tabela 1. Udzial w przedsięwzięciach proekologicznych.

\begin{tabular}{|c|c|c|c|c|c|c|c|}
\hline Przedsięwzięcia & 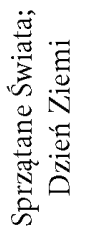 & 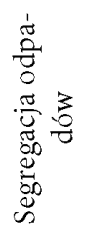 & 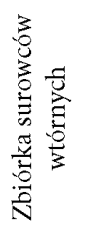 & 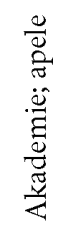 & 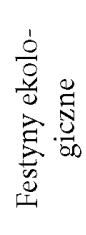 & 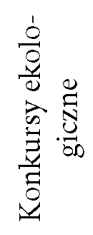 & 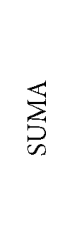 \\
\hline Wskazania & 56 & 19 & 7 & 31 & 8 & 39 & 160 \\
\hline$\%$ & 37.3 & 12.7 & 4.7 & 20.7 & 5.3 & 26.0 & - \\
\hline
\end{tabular}

* procenty nie sumują się do stu ze względu na wielokrotną możliwość wyboru odpowiedzi.

Analiza wyników zestawionych w tabeli 1 sugeruje, że największą popularnością wśród podejmowanych działań proekologicznych cieszy się akcja „Sprzątanie Świata", ponieważ $37.3 \%$ respondentów w niej uczestniczyło. Natomiast $26.0 \%$ 
brało udział w organizowanych „konkursach ekologicznych”, akademiach i apelach okolicznościowych. Segregacja odpadów wskazana została tylko przez $12.7 \%$ populacji objętej badaniami, również zbiórka surowców wtórnych, tylko 4,7\% uczniów wymieniło ją w ankiecie, a organizowane w celu propagowania idei ochrony przyrody „festyny ekologiczne” tylko 5.3\% - ryc. 3 .

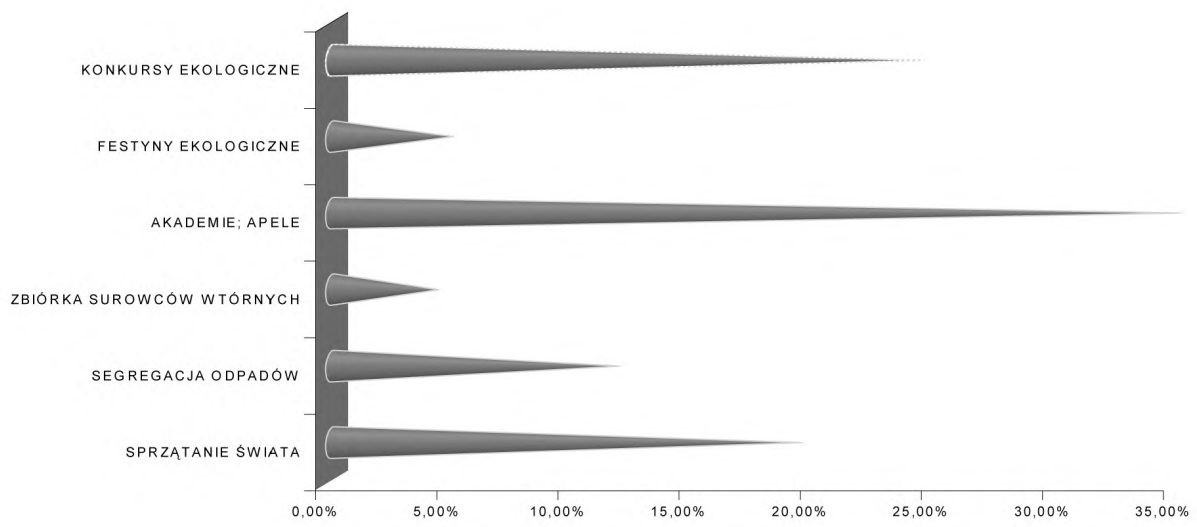

Ryc. 3. Udział w przedsięwzięciach proekologicznych.

W odpowiedzi uczniów na pytanie o własne propozycje działań na rzecz ochrony środowiska najczęściej podawane były - według kolejności wskazań:

1. zbieranie odpadów $-43,4 \%$,

2. segregacja odpadów $-20,6 \%$,

3. wykonywanie plakatów o tematyce środowiskowej - 10,5\%,

4. wzbogacanie terenów o dodatkową zieleń - 5,2\%,

5. brak propozycji $-20,3 \%$.

$\mathrm{Z}$ analizy uzyskanych danych dotyczących znajomości organizacji zajmujących się ochroną środowiska wynika, że Liga Ochrony Przyrody jest powszechnie znana wśród uczniów, ponieważ 97 na 150 ankietowanych ją wymieniło, natomiast pozostałych 53 respondentów nie potrafiło podać żadnego przykładu organizacji prośrodowiskowej. Przynależność do Koła biologicznego zadeklarowało $19 \%$, ale tylko uczniowie zdający biologię w kanonie rozszerzonym na maturze, pozostałe $81 \%$ nie wykazało zainteresowania przynależnością do żadnych organizacji krzewiących idee ochrony przyrody. Z prezentacją bieżących informacji dotyczących ekorozwoju ankietowani spotkają się również w mediach (37\%) oraz w prasie (16\%), ale dla większości (47\%) szkoła jest nadal jedynym źródłem wiadomości na ten temat. $Z$ analizy danych wynika, że już na wcześniejszych etapach edukacyjnych przede wszystkim w gimnazjum te wiadomości zostały im przekazane. 
W odpowiedzi na kolejne pytanie ankietowani (62.8\%) stwierdzili, że znają różne czasopisma uwzględniające tematykę z zakresu ekologii i ochrony środowiska umiejąc podać ich tytuły. Wśród wymienionych znalazły się według kolejności wskazań: „Świat Wiedzy”; „National Geagrafic”; „Aura”; „Focus”. Niepokojący jest fakt, że aż $24.5 \%$ respondentów nie udzieliło odpowiedzi na to pytanie, co świadczy o braku zainteresowania pozyskiwaniem informacji z czasopism. 10\% respondentów czerpało informacje na ten temat z takich źródeł jak książki. Dosyć dużą popularnością, bo aż 55\% wskazań cieszyły się programy telewizyjne o tematyce środowiskowej, natomiast internet jako źródło wiarygodnych informacji poparty był przez 79,2\%. Wśród innych źródeł wymieniono lekcje biologii, chemii, geografii oraz wycieczki, co stanowi $22,5 \%$ odpowiedzi. Bardzo ważnym aspektem wychowawczym, kształtującym prawidłowe postawy młodzieży wobec środowiska, jest poruszanie tej problematyki podczas rozmów z najbliższymi często w domu rodzinnym. Okazuje się, że $11 \%$ respondentów inicjuje tą tematykę, ale tylko $2 \%$ bardzo często o tym rozmawiało. Dalece niezadowalający jest fakt, że aż $87 \%$ nie porusza tego tematu wcale.

W celu ochrony przyrody ankietowani (25\%) właściwie wykorzystaliby surowce wtórne, segregowaliby odpady i zwiększyliby liczę koszy na ulicach. 19\% młodzieży twierdzi, że nałożyłoby kary pieniężne na tych, którzy nie przestrzegają przepisów dotyczących ochrony środowiska, a 16\% zbudowałoby nowoczesne oczyszczalnie ścieków, 11\% jest zadania, że należy uświadomić społeczeństwo o skutkach degradacji. Natomiast, aby nie przyczyniać się do dalszej degradacji przyrody warto:

- przeznaczyć większe fundusze na rzecz ochrony przyrody,

- kształtować świadomość ekologiczną społeczeństwa,

- objąć edukacją całe społeczeństwo,

- unowocześnić technologię produkcji,

- wdrożyć obowiązujące w UE programy ochrony środowiska,

- utworzyć nowe tereny zieleni,

- propagować informacje na ten temat w mediach,

- egzekwować przestrzeganie prawa,

- właściwie wykorzystać surowce wtórne.

Natomiast zdania na temat wyboru opakowania kupowanego towaru byly znacznie podzielone i odpowiedzi udzieliło tylko 100 osób. Wyniki analizy tego zagadnienia zestawiono w tabeli 2 . 
Tabela 2. Wybór opakowania towaru.

\begin{tabular}{|l|c|c|}
\hline \multicolumn{1}{|c|}{ Możliwość wyboru } & Liczba odpowiedzi & $\%$ \\
\hline Nie ma to dla mnie znaczenia. & 34 & 34 \\
\hline Zwracam uwagę na estetykę towaru. & 25 & 25 \\
\hline $\begin{array}{l}\text { Wybieram opakowania z tworzyw sztucznych (np. folia } \\
\text { polietylenowa). }\end{array}$ & 19 & 19 \\
\hline Kupuję towary tylko w opakowaniach ekologicznych. & 22 & 22 \\
\hline SUMA & 100 & 100 \\
\hline
\end{tabular}

Wysunięte na pierwszy plan stwierdzenie mówiące o wyborze opakowania jako czynności bez znaczenia jest dosyć niepokojące, ponieważ określiło się w ten sposób $34 \%$ ankietowanych, a $22 \%$ z nich kupowało towary w opakowaniach ekologicznych. Estetyka opakowania miała duże znaczenie dla $25 \%$ respondentów, natomiast $19 \%$ stwierdziło, że wybiera tylko opakowania z tworzyw sztucznych. Zależności te przedstawiono na poniższym rysunku.

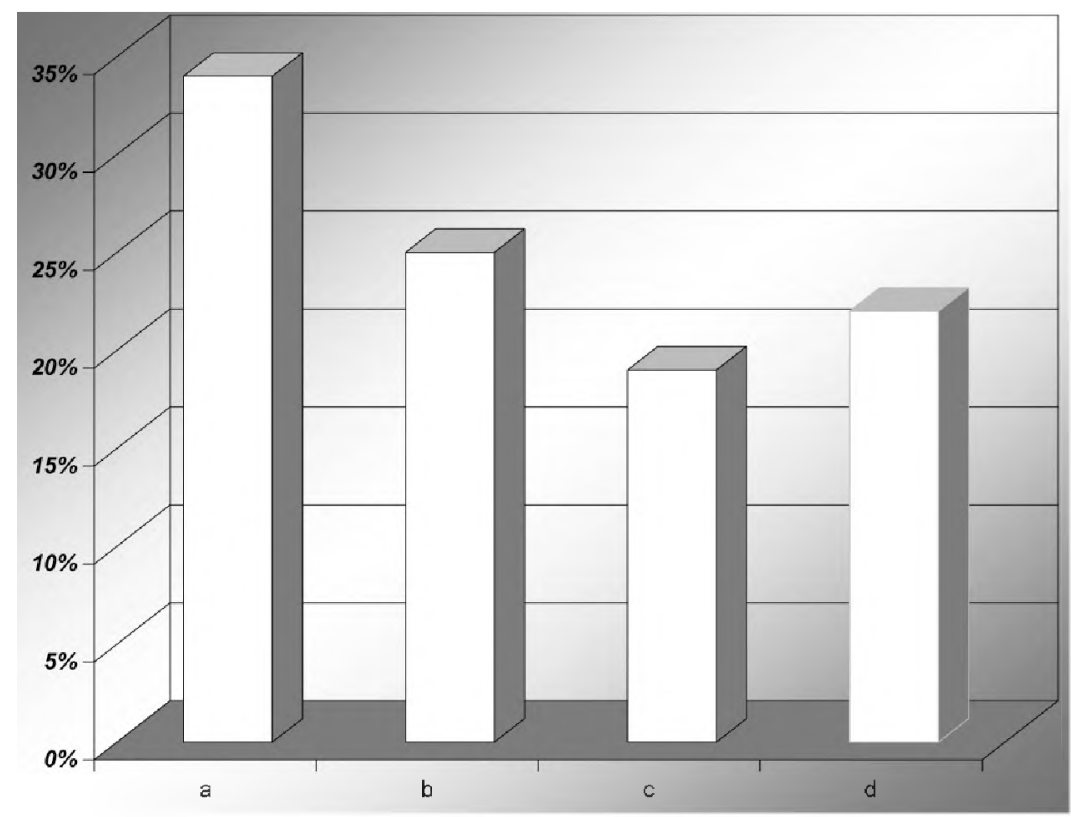

Ryc. 4. Wybór opakowania towaru. 
Większość ankietowanych zapytana o sposób poprawy stanu środowiska w swojej okolicy wysunęła następujące własne propozycje:

1. zbieranie odpadów,

2. segregacja odpadów,

3. podejmowanie w miejscu zamieszkania akcji mających na celu promowanie działań na rzecz ochrony przyrody,

4. wzbogacanie o dodatkową zieleń terenów ubogich w nią.

Brak jakichkolwiek propozycji zanotowano wśród 38,3\% respondentów, co jest zjawiskiem dosyć niepokojącym. W odpowiedzi na kolejne pytanie zamieszczone w kwestionariuszu ankiet uczniowie stwierdzili, że w celu zmobilizowania ludzi do właściwego zachowania się w środowisku zgodnie z zasadami zrównoważonego rozwoju należy nagłaśniać tą problematykę w mediach, prezentować fakty dotyczące nieprawidłowego zachowania, oraz promować innowacyjne przedsięwzięcia, które już są realizowane przez społeczność lokalną. Dokonując analizy uzyskanych danych z przeprowadzonych badań stwierdzono, że należy nie tylko w sposób obligatoryjny nałożyć na nauczycieli obowiązek realizacji zagadnień dotyczących tej problematyki, ale również egzekwować jej skuteczność i efektywność.

Nauczyciel poszukujący, zaangażowany i twórczy powinien motywować swoich wychowanków do podejmowania działania, gdyż pozwoli to im wykazać się własną inicjatywą, a to z kolei przyczyni się do rozwoju ich osobowości. Uczeń podejmujący działanie po pewnym czasie przyjmie postawę wykonywania danego rodzaju działania. Stanie się zwolennikiem tego działania, będzie zachęcał innych, często będzie pełnił odpowiednią funkcję. Najwyższą, osiągalną kategorią celów motywacyjnych jest system działań, gdzie uczeń nie zawodzi nawet w trudnych sytuacjach, jego działania są skuteczne, a zdobyte wiadomości i umiejętności potrafi zastosować w każdym przypadku. ${ }^{7}$

Cele, treści i osiągnięcia, zamieszczone w podstawie programowej nauczania biologii w szkołach ponadgimnazjalnych, stanowią rozszerzenie i wzbogacanie wiedzy nabytej przez uczniów w gimnazjum. Podstawa programowa ekologicznej ścieżki zawiera bardzo ważne treści społeczno - wychowawcze. Ich realizacja powinna wpływać na kształtowanie postaw oraz branie odpowiedzialności za obecny i przyszły stan środowiska, a także gotowość do działań na rzecz zrównoważonego rozwoju. ${ }^{8}$

7 JAGODZIŃSKA M. 2005: Zalożenia programowe i charakterystyka procesu edukacyjnego w zakresie ksztatcenia przyrodniczego. [w:] Ksztatcenie przyrodnicze w szkole podstawowej-teoria i prakty$k a$. Red. D. Cichy Ośrodek Doskonalenia Nauczycieli Płock s. 22.

8 D. Cichy 2003: Szkoła wobec wyzwań edukacji biologicznej iśrodowiskowej w XXI wieku. Instytut Badań Edukacyjnych, Warszawa s. 35. 


\section{Zakończenie}

W dobie wdrażania założeń reformy treści te powinny być zawarte we wszystkich programach i podręcznikach, a ich realizacja musi obejmować wszystkie etapy kształcenia, ale nie tylko poprzez edukację formalną, za którą odpowiada szkoła. Ogromną rolę odgrywa tutaj również edukacja nieformalna skierowana do całego społeczeństwa, wszystkich mieszkańców Polski. Zmieniające się programy szkolne, trendy dydaktyczne, metody i formy pracy zmuszają do ustawicznego doskonalenia się, sięgania po materiały aktualizujące wiedzę nauczycieli zarówno merytoryczną i metodyczną.

Nauczyciel przygotowany w ten sposób będzie mógł oprzeć swą pracę nad kształceniem dzieci i młodzieży dla zrównoważonego rozwoju na racjonalnych podstawach. Wszyscy zdają sobie sprawę z ogromnej roli ciągłego doskonalenia nauczycieli, ale nadal nie obejmuje ono wszystkich niezbędnych obszarów działalności szkoły. Na podstawie analizy wyników badań przeprowadzonych przez Buchcic (2005) stwierdzono, że nauczyciele nie uzyskają odpowiednich kompetencji w zakresie kształcenia do wdrażania zasad zrównoważonego rozwoju ponieważ oferta edukacyjna różnych instytucji zajmujących się edukacją (oprócz ośrodków akademickich) skierowana do nauczycieli jest zbyt uboga w tym zakresie i ich nie zawiera. ${ }^{9}$

\section{LITERATURA}

Bielska A. 2006: Rola Ministerstwa Srodowiska w Kształtowaniu świadomości Ekologicznej Spoleczeństwa. Edukacja Biologiczna i Środowiskowa. nr 3 s. 25.

Buchcic E. 2005: Przygotowanie nauczycieli do wdrażania zasad zrównoważonego rozwoju. [w:] Edukacja środowiskowa wzmocnieniem zrównoważonego rozwoju. Red. D. Cichy IBE, WSP ZNP, Warszawa s. 109.

CICHY D. 2003: Szkoła wobec wyzwań edukacji biologicznej i środowiskowej w XXI wieku. Instytut Badań Edukacyjnych, Warszawa s. 35.

Cichy D. 2005: Edukacja środowiskowa wzmocnieniem zrównoważonego rozwoju. Instytut Badań Edukacyjnych. Wyższa Szkoła Pedagogiczna ZNP, Warszawa s. 5.

Сıсну D. 2005: Uwarunkowania edukacji dla zrównoważonego rozwoju. [w:] Edukacja środowiskowa wzmocnieniem zrównoważonego rozwoju. Red. D. Cichy IBE, WSP ZNP, Warszawa s. 26.

JAGODZIŃsKa M. 2005: Założenia programowe i charakterystyka procesu edukacyjnego $w$ zakresie ksztalcenia przyrodniczego. [w:] Ksztalcenie przyrodnicze w szkole podstawowej-teoria i praktyka. Red. D. Cichy Ośrodek Doskonalenia Nauczycieli Płock s. 22.

Stownik Wspólczesnego Języka Polskiego tom l. WILGA, Warszawa. 1998, s. 226.

9 BuchcIC E. 2005: Przygotowanie nauczycieli do wdrażania zasad zrównoważonego rozwoju. [w:] Edukacja środowiskowa wzmocnieniem zrównoważonego rozwoju. Red. D. Cichy IBE, WSP ZNP, Warszawa s. 109. 


\title{
Education for the balanced development in the development of high schools
}

\author{
SUMMARY
}

The aim of the realisation of the material is getting the results of carried on research concerning the fact of finding out to what level contents involving the balanced development during the educational activities was introduced, moreover, what influence of such issues on the creating the right attitudes towards the pro-ecological awareness of young people was.

The balanced development is at present the challenge for creating the awareness not only of the particular society, but also in the widest sense the whole generation of people.

Undertaking such issues the role of education during all stages of teaching should be taken into consideration, especially, in the range of propagating the idea of responsibility for the natural environment with eco-development. It is a specially important element of teaching according to the principle of pro-environmental education to undertake all actions in the educational centers, which aim is to stimulate the environmental awareness of young people as well as to prepare the pedagogical staff to the realization of the wide range of methods and strategies that allow to get the best results during the process of educating young generation.

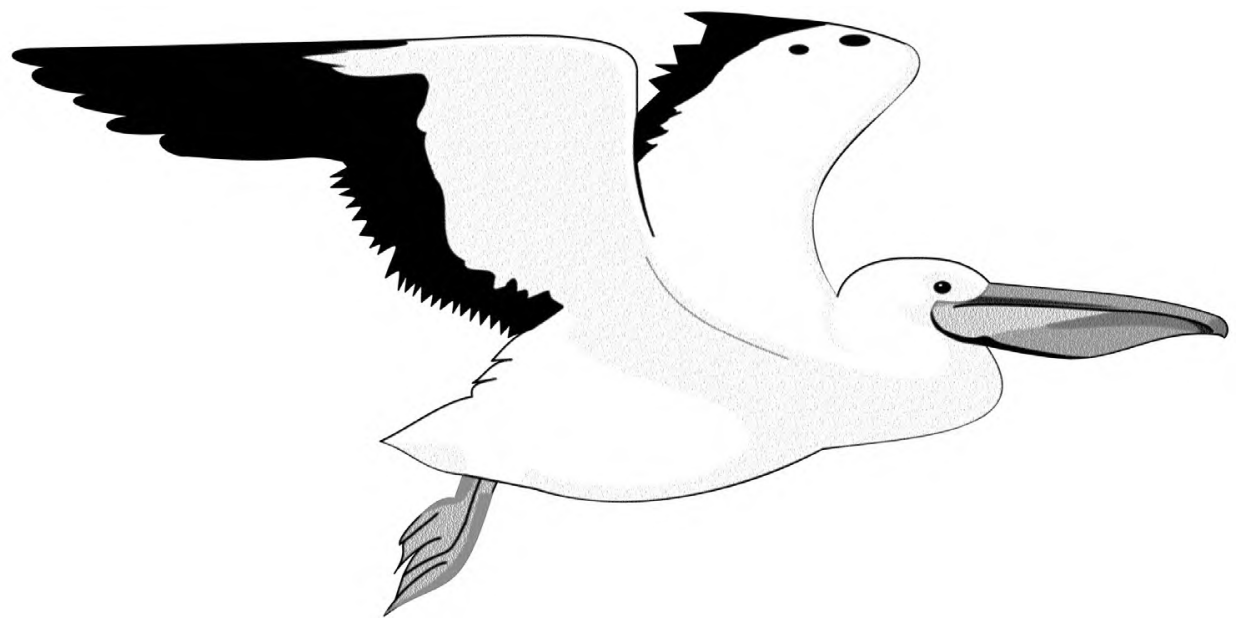

